\title{
Age Peculiarities of Psychological Adaptation of Ukrainian Winterers for Life in Antarctic Conditions
}

\section{Вікові особливості психологічної адаптації українських зимівників до життєдіяльності в умовах Антарктики}

\begin{abstract}
Olena Miroshnychenko
Ph.D. in Pedagogy, Assistant Professor, Department of Pedagogy, Professional Education and Management of Educational Institutions, Zhytomyr Ivan Franko State University, Zhytomyr (Ukraine)

ORCID ID: https://orcid.org/0000-0002-5712-3752

E-mail: perspektiva-z@ukr.net

\section{Олена Мірошниченко}

Кандидат педагогічних наук, доцент кафедри педагогіки, професійної освіти та управління освітніми закладами, ЖКитомирський державний університет імені Івана Франка, м. ЖКитомир (Україна)
\end{abstract}

\section{Igor Pasichnyk}

Dr. in Psychology, Professor, Rector of the National University of Ostroh Akademy, Ostroh (Ukraine)

ORCID ID: https://orcid.org/0000-0001-7785-2584

E-mail: oa@oa.edu.ua

\section{Ігор Пасічник}

Доктор психологічних наук, професор, ректор Національного університету «Острозька академія», м. Острог (Україна)

Address for correspondence, e-mail: kpnu_lab_ps@ukr.net Copyright: (C) Miroshnychenko Olena, Pasichnyk Igor

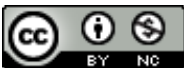
The article is licensed under CC BY-NC 4.0 International (https://creativecommons.org/licenses/by-nc/4.0/)

(C) Miroshnychenko Olena, Pasichnyk Igor

DOI (article): https://doi.org/10.32626/2227-6246.2020-48.228-252 http://journals.uran.ua/index.php/2227-6246 
DOI: https://doi.org/10.32626/2227-6246.2020-48 2020. виПУСК 48

The author's contribution: O. Miroshnychenko-50\%, I. Pasichnyk - 50\%. Авторський внесок: О. Мірошниченко - 50\%, І. Пасічник - 50\%.

\section{ABSTRACT}

The peculiarities of winterers' psychological adaptation to extreme conditions of life article are discussed in the article. In winter Ukrainian polar explorers, who make researches by the directions consolidated by the State Program, stay long on the limited territory, so that they need adaptation to social isolation and psychological deprivation. In addition, the adaptation of winterers takes place in the severe climate, and it much depends on the readiness of the participants of expedition to the fulfillment of professional responsibilities in the extreme conditions.

The aim of the article is to present theoretical bases and practical results of researches on age peculiarities of psychological adaptation of Ukrainian winterers for life in Antarctic conditions on the example of the last 9 expeditions to the Ukrainian Antarctic station "Academician Vernadskyi».

Methods. The complex of methods of psychological researches of adaptation processes of personality of a certain age is used. The experiment involved 70 winterers who have been in Antarctica during the year from 2011 to 2019.

The results of the research. The results of empirical studies on adaptation rates in winterers of different age groups for previous representatives are presented. After the comparison of survey results during the expedition the presence of changes in psychological characteristics was revealed. It was found that during the stay in Antarctica, some winterers experienced psycho-emotional problems, and revealed typical psychological and psychophysiological changes. It was found that the most difficult period of life was the period of the Antarctic winter.

Conclusions. The most adapted age group for life in Antarctic is proved to be middle-aged adults aged from 35 to 45 years. The representatives of this group make up about $40 \%$ of participants of the Ukrainian Antarctic expeditions that testifies to the sufficient level of psychological stability of wintering teams.

Key words: adaptation, adaptability, life in Antarctic, readiness, preparation for extreme activity, age groups of adulthood.

(C) Miroshnychenko Olena, Pasichnyk Igor DOI (article): https://doi.org/10.32626/2227-6246.2020-48.228-252 


\section{Вступ}

До 1991 р. багато українських науковців у складі радянських експедицій активно досліджували Шостий континент - Антарктиду. Ставши самостійною державою, Україна одразу приєдналася до Договору про Антарктиду, а з 1996 p. увійшла до складу 19 держав, що мають в Антарктиці постійно діючі станції. Для науковців країни це не тільки почесно, а й дуже відповідально, адже високоширотні зони планети є своєрідним дзеркалом, у якому відображаються усі процеси змін на Землі.

Така почесна міжнародна місія поставила перед науковцями України принципово нові й важливі завдання. Від рівня підготовки фахівців, які виконують професійну діяльність в умовах Антарктики, залежить майбутне не тільки держави, а й міжнародного співробітництва.

Вивчення досвіду роботи Національного антарктичного наукового центру МОН України показало, що вітчизняні дослідження Антарктики спрямовані на фундаментальні та прикладні проблеми, що поділяються на напрями: геолого-геофізичний, гідрометеорологічний, геокосмічний, біологічний, медико-фізіологічний.

Наші психологічні дослідження пов'язані з психофізіологічною та соціально-психологічною складовими у психіці полярника. Основним питанням дослідження є психологічна підготовка українського зимівника до довготривалого перебування в Антарктиці. Упродовж попередніх 9 років відбувається співпраця між Національним антарктичним науковим центром Міністерства освіти і науки України та вищими освітніми закладами України. Авторка цієї публікації у якості члена 19-ї Міжсезонної наукової антарктичної експедиції у 2014 р. відвідала українську антарктичну станцію «Академік Вернадський», яка знаходиться на острові Галіндез у складі архіпелагу Аргентинські острови біля Антарктичного півострова з географічними координатами (c) Miroshnychenko Olena, Pasichnyk Igor

DOI (article): https://doi.org/10.32626/2227-6246.2020-48.228-252 
$65^{\circ} 15 r^{\wedge}$ пн. ш. i $64^{\circ} 16 r^{\wedge}$ зх. д. Станція є сучасною науковою лабораторією, що обладнана новітньою вимірювальною технікою, укомплектована житловими та допоміжними приміщеннями i побутовим обладнанням. Експедиційна діяльність екіпажу станції (11-13 осіб) базується на виконанні наукових досліджень та обслуговуванні технічних приладів. Особливості життєдіяльності зимівників пов'язані з тривалим (до 13 місяців) перебуванням на обмеженій території, що спричиняє соціально-психологічну ізоляцію, сенсорну та комунікативну депривацію. Також адаптація зимівників проходить в умовах суворого клімату та гідрометеорологічних особливостей і великою мірою залежить від стабільності психоемоційного стану учасників експедиції, а він, своєю чергою, грунтується на системі готовності до життєдіяльності в Антарктиці.

Тому вкрай важливим є вирішення питання підготовки українських зимівників до їх довготривалого перебування в Антарктиді.

Мета статті - представити теоретичні основи та практичні результати досліджень вікових особливостей психологічної адаптації українських зимівників до життєдіяльності в умовах Антарктики на прикладі 9 експедицій до української антарктичної станції «Академік Вернадський».

\section{Завдання статті}

1. Уточнити поняття адаптації до екстремальних умов життедіяльності.

2. Визначити вікові межі досліджуваних груп українських зимівників.

3. Представити методологічний інструментарій психологічного дослідження.

4. Продемонструвати результати дослідження вікових особливостей адаптації до екстремальних умов життєдіяльності на прикладі 9 останніх експедицій до української антарктичної станції «Академік Вернадський».

(C) Miroshnychenko Olena, Pasichnyk Igor DOI (article): https://doi.org/10.32626/2227-6246.2020-48.228-252 


\section{Методи та методики дослідження}

Для досягнення визначеної мети і поставлених завдань нами використовувалися різні групи методів: організаційні, емпіричні, методи обробки даних та інтерпретаційні. Організація досліджень перед початком чергової української антарктичної експедиції узгоджується з програмою технічних і психологічних завдань Національного антарктичного наукового центру (НАНЦ) України. Серед емпіричних методів у нашій статті було застосовано спостереження та самоспостереження, серед психодіагностичних - представлено результати використання методики щодо вивчення акцентуацій характеру, а саме: «Методики визначення акцентуацій характеру» К. Леонгарда і Г. Шмішека, оскільки вона надає достовірну інформацію щодо змін психологічних станів особистості під впливом довгострокового перебування в несприятливих умовах. Із групи методів обробки даних було використано кількісний (математична статистика; порівняння середніх значень за допомогою параметричних і непараметричних методів) і якісний (диференціювання матеріалу за віковими групами досліджуваних). Із групи інтерпретаційних - використано структурну та якісну інтерпретацію особливостей отриманих результатів.

Показники адаптації представлено через стани особистості, які ми досліджували за допомогою шкал акцентуацій (застрягання, педантизм, тривожність, дистимність, збудженість) за методикою К. Леонгарда і Г. Шмішека (Райгородський, 2008). Згідно наших багаторічних спостережень i емпіричних досліджень, збільшення показників саме цих шкал в окремих представників команди у першій половині зимівлі свідчить про недостатню адаптацію до екстремальних умов життєдіяльності та призводить до порушень соціальних стосунків у колективі. Отримані результати методик були підтверджені шляхом застосування допоміжного методу - бесід, які проводилися з досліджуваними. Застосуван(C) Miroshnychenko Olena, Pasichnyk Igor

DOI (article): https://doi.org/10.32626/2227-6246.2020-48.228-252 
ня зазначених методів забезпечило надійність і валідність нашого дослідження.

Також нами було виявлено, що адаптація до суворих умов перебування в Антарктиці певним чином залежить від вікових особливостей учасників зимівлі. 3 метою дослідити такі закономірності всі учасники нашого природного експерименту були умовно поділені на три вікові групи: 22-34 роки, 35-45 років, старші 45 років. Обгрунтування такого поділу та результати досліджень представлено нижче.

\section{Результати та дискусії}

Адаптація - складне та багаторівневе явище пристосування, включення особи як у мікро-, так і в макросередовище життєдіяльності. Спираючись на дослідження А. Налчаджяна, ми виходимо з припущення, що добре адаптована людина - це така особистість, у якій продуктивність, здатність насолоджуватися життям і психічна рівновага не порушені (Налчаджян, 2010).

Проблемою адаптації до екстремальних умов життєдіяльності українських зимівників займається група науковців (медиків, фізіологів, психологів) Національного антарктичного наукового центру впродовж тривалого часу. Вони довели, що у процесі адаптації в період зимівлі змінюється не тільки індивід, а й середовище, внаслідок чого між ними встановлюється відношення адаптивності, не завжди врівноважене, оскільки експедиційна діяльність пов'язана 3 впливом на зимівників численних екстремальних чинників (особливості регіональної фотоперіодики, зсув часових поясів, сенсорна депривація, активація метео- та геліофізичних явищ тощо), що створює додаткове навантаження на функціональні системи організму (Moiseienko, Sukhorukov, Pyshnov, Mankovska, Rozova, Miroshnychenko et al., 2016).

Адаптивна поведінка особистості, яка працює в екстремальних умовах, характеризується прийняттям рішення, правом ініціативи і точним визначенням свого майбутнього.

(C) Miroshnychenko Olena, Pasichnyk Igor DOI (article): https://doi.org/10.32626/2227-6246.2020-48.228-252 
У нашому дослідженні ми спираємося саме на це розуміння соціально-психологічної адаптації особистості, оскільки в ньому відображається ідея активності особистості. Активна особистість здійснює переважно цю форму адаптації, вона не відходить від проблемних ситуацій, а використовує їх для реалізації своїх цілей, сама планує, здійснює своє майбутне та переборює труднощі. А. Налчаджян як специфічні особливості соціально-психологічної адаптації відзначав активну участь свідомості, вплив професійної діяльності людини на середовище та зміну способів власної адаптації відповідно до соціальних умов життєдіяльності (Налчаджян, 2010: 86).

Серед різновидів соціально-психологічної адаптації ми розрізняємо такі. Норлальна адаптація - це процес, що призводить до якісної адаптованості в проблемних ситуаціях без патологічних змін структури особистості й одночасно без порушення норм тієї соціальної групи, у якій проходить iї активність. Своєю чергою, нормальна адаптація поділяється на захисну і незахисну. Нормальна захисна - ті дії особистості, що здійснюються за допомогою захисних механізмів (раціоналізації, регресії, формування зворотної реакціï), якщо ці механізми не стали патологічними. Нормальна незахисна адаптація відрізняється тим, що починається у таких проблемних ситуаціях, які вимагають від особистості прийняття раціональних рішень, що здійснюються без участі відомих захисних механізмів за допомогою незахисних адаптивних комплексів. Для досягнення адаптації в умовах виникнення проблемних нефруструючих ситуацій, що можуть виникати в екстремальних умовах зимівлі, використовуються пізнавальні процеси особистості, процеси цілеутворення і групові соціально-психологічні механізми. Звичайно, така форма адаптації є найприйнятнішою в умовах замкненого колективу.

Девіантна адаптація забезпечує задоволення потреб особистості в певній групі, причому очікування інших учас() Miroshnychenko Olena, Pasichnyk Igor

DOI (article): https://doi.org/10.32626/2227-6246.2020-48.228-252 http://journals.uran.ua/index.php/2227-6246 
ників соціального процесу не виправдовуються такою поведінкою. Ми поділяємо її на неконформістську й інноваційну. Неконформістська - такий процес адаптації особистості, завдяки якому вона долає внутрішню групову проблемну ситуацію незвичайними для членів цієї групи способами і внаслідок цього опиняється в конфліктних стосунках із нормами групи та їх носіями. На жаль, випадки конфліктів упродовж тривалого перебування в несприятливих умовах і замкненому колективі трапляються практично в усіх зимівлях, і кожен колектив, у першу чергу, завдяки вмінням і досвіду керівника, знаходить виходи з конфліктних ситуацій.

Інноваційна (новаторська), або творча, адаптація - це така діяльність, у процесі якої особистість створює нові цінності, здійснює нововведення в тій чи іншій галузі життєдіяльності. Цей різновид девіантної адаптації є наймогутнішим чинником прогресу, основним засобом попередження застою та регресу.

Патологічна адаптація - соціально-психологічний процес, який повністю або частково здійснюється за допомогою патологічних механізмів і форм поведінки й призводить до утворення патологічних комплексів характеру, що входять до складу невротичних психопатичних синдромів. У процесі патологічної адаптації використовуються такі захисні механізми, які виводять поведінку особистості за межі нормальної. За 9 років нашого дослідження поведінки зимівників під час зимівлі лише у трьох із них траплялися випадки патологічної адаптації, що потребували медичних втручань із боку лікаря експедиції.

Дослідження адаптації особистості до екстремальних умов довели, що велику роль у цьому процесі відіграє готовність зимівника до життєдіяльності в Антарктиці. Згідно з нашими дослідженнями, готовність базується на двох основних складових: психофізіологічних якостях і мотивації до діяльності. Психофізіологічні функції працюючих в екс-

(C) Miroshnychenko Olena, Pasichnyk Igor DOI (article): https://doi.org/10.32626/2227-6246.2020-48.228-252 
тремальних умовах повинні відповідати таким вимогам, як: висока емоційна стійкість; стійкість до втоми; виразні ознаки сильного, врівноваженого, рухливого типу вищої нервової діяльності; високі показники сенсомоторних реакцій, швидкості переключення уваги; хороша зорова та слухова пам'ять (Мірошниченко, 2016; Мірошниченко, 2018).

Готовність до діяльності включає оцінювання своїх можливостей у співвідношенні з майбутніми труднощами, упевненість у собі та своїй підготовленості, цілеспрямованість, самостійність при прийнятті рішення, самовладання, вміння керувати своїми емоціями тощо. O. Sannikov, говорячи про операторів інформаційних систем, які працюють в екстремальних умовах, також визначає провідну роль самостійності й соціального досвіду особистості серед компонентів системи прийняття рішення у складних ситуаціях (Sannikov, 2016). Це ж підтверджують і наші дані.

М. Корольчук і В. Крайнюк зазначають, що готовність до діяльності містить не тільки різноманітні усвідомлені чи неусвідомлені настанови на певні форми реагування, а й усвідомлення завдання, моделі вірогідної поведінки, визначення оптимальних засобів діяльності, оцінювання своїх можливостей у співвідношенні з майбутніми труднощами (Корольчук \& Крайнюк, 2006).

Особливості адаптації до професійної діяльності досліджують I. Perelyhina й I. Mykhliuk. Вони прослідковують прояви акцентуацій в адаптації до професійної діяльності у службовців Міністерства надзвичайних ситуацій, які також виконують свої обов'язки в екстремальних умовах. Їхні дані свідчать про більш виражену, ніж у зимівників, форму акцентуацій характеру, які призводять до виникнення професійного стомлення у службовців (Perelyhina \& Mykhliuk, 2017).

Вітчизняна дослідниця міжособистісних стосунків у колективах зимівників L. Bakhmutova акцентує увагу на тому, (C) Miroshnychenko Olena, Pasichnyk Igor

DOI (article): https://doi.org/10.32626/2227-6246.2020-48.228-252 
що процеси фізіологічної та психологічної адаптації тісно пов'язані 3 процесами встановлення соціальних зв'язків між членами довготривалих експедицій: чим вищим є соціальний статус зимівника, тим краще відбуваються у нього процеси адаптації (Bakhmutova, 2019).

Зарубіжні дослідники з тих країн, що мають постійно діючі антарктичні станції, також відзначають складності психологічної адаптації до суворих умов Антарктики. Так, M. Mehta i G. Chugh установили, що важливу роль у пристосуванні до важких умов відіграють такі соціальні риси особистості, як ентузіазм, відповідальність, оптимістична орієнтація на майбутнє, сміливість, рішучість і потреба у самореалізації (Mehta \& Chugh, 2011).

На нашу думку, одним з основних мотивів, що сприяє адаптації до роботи далеко від Батьківщини і рідної домівки, є просоціальний мотив. Як стверджують самі зимівники, «тільки там, в Антарктиці, я відчуваю себе необхідним суспільству, важливим для інших, потрібним людству». До просоціальних мотивів у членів експедиції належать такі, що пов'язані з усвідомленням суспільного значення діяльності, з почуттям обов'язку, відповідальності перед групою або суспільством загалом. Для справжнього зимівника вони часто є більш значущими, ніж матеріальні або пізнавальні, а проявляються найбільше, за нашими даними, у середній віковій групі (35-45 років).

Отже, психологічна підготовка особового складу зимівників до життєдіяльності в умовах Антарктики є профілактикою стресів і професійної втоми упродовж зимівлі, а дослідження психологічних характеристик особистості складають основу професійної підготовки до діяльності в екстремальних умовах.

Починаючи з XVI Української антарктичної експедиції на станцію "Академік Вернадський», ми проводимо психологічні дослідження зимівників за чотирма параметрами:

(C) Miroshnychenko Olena, Pasichnyk Igor DOI (article): https://doi.org/10.32626/2227-6246.2020-48.228-252 
DOI: https://doi.org/10.32626/2227-6246.2020-48 2020. ВипУСК 48

- діагностика нейродинамічних і психічних якостей особистості (вивчення властивостей темпераменту, дослідження наявності акцентуацій характеру);

- дослідження психічних пізнавальних процесів (мислення, пам'ять) і проявів характеру (організованість, працелюбність, допитливість тощо);

- дослідження показників міжособистісних взаємовідносин членів групи в умовах ізоляції (визначення способів виходу із конфліктних ситуацій, соціальний статус кожного учасника експедиції);

- визначення показників соціально обумовленої підструктури особистості (рівень самооцінки зимівника та переважаюча мотивація професійної діяльності).

Заміри психологічних параметрів (зрізів) відбуваються чотири рази: в період формування членів експедиційної команди (лютий-березень відповідного року експедиції), в середині зимівлі (червень-липень відповідного року експедиції), в період початку відкриття станції для відвідувачів (листопад відповідного року експедиції) та в кінці зимівлі (березень року повернення).

Нами було створено методичні розробки щодо проведення психологічних досліджень українських зимівників, за якими ми провели дослідження 70 зимівників за період 2011-2019 pp. (Мірошниченко, Моісеєнко \& Литвинов, 2015).

Зазвичай, діяльність зимівника завжди обумовлюється комплексом, поєднанням зовнішніх і внутрішніх психологічних якостей. Вони з'ясовуються шляхом досить тривалого спілкування психолога з претендентами на учасників експедиції, яке відбувається в умовах, соціально та психологічно наближених до умов перебування в експедиції - проживання всієї команди разом в окремому будинку на умовно закритій території. У таких умовах відбувається перевірка майбутніх зимівників на психологічну сумісність, на вміння виконувати професійні обов'язки (наприклад, механіка, лі() Miroshnychenko Olena, Pasichnyk Igor

DOI (article): https://doi.org/10.32626/2227-6246.2020-48.228-252 http://journals.uran.ua/index.php/2227-6246 
каря, кухаря), відпрацьовуються навички працювати разом, проводити дозвілля в межах замкненого колективу тощо. Під час зборів психолог проводить психологічні обстеження, а саме: спостереження, індивідуальні бесіди, ділові ігри, тестування за допомогою методик. Згідно розробленої концепції типології українського зимівника, найбільша увага приділяється адаптаційним можливостям особистості, яка зимуватиме далеко від домівки і звичних умов. Ми досліджуємо акцентуації характеру зимівників, оскільки через їх прояви можемо судити про наявність або відсутність ознак стресу, професійної втоми, невротичних реакцій.

Характер особистості, яка працює в екстремальних умовах, не тільки проявляється в іiі діях, учинках, а й накладає на них свій відбиток. Від того, який характер у людини, залежить, як вона діє за певних обставин, як домагається реалізації своїх цілей, своїх ідейних прагнень. Звідси стає зрозуміло, якою важливою якістю працівника є його цільний, сильний, виразний характер і наскільки актуальним $\epsilon$ психологічне вивчення характерів працюючих в екстремальних умовах і шляхів їх оптимізації.

Отже, структура особистості зимівників, яких ми досліджуємо, має складну ієрархічну будову, що формується на основі індивідуальних якостей і впливу відповідних соціальних умов. Особистісні характеристики мають тісний зв'язок зі станом психофізіологічних функцій, які адаптуються до змінених умов життєдіяльності та певним чином реагують на дію екстремальних чинників. Такі зрушення можуть відображатися на якості психічних і психофізіологічних характеристик людини.

Спираючись на матеріали Г. Пишнова, який досліджував механізми формування хронічної втоми за високої напруженості праці, ми створили схему причин професійного стомлення, що може виникнути у зимівників під впливом несприятливих умов життєдіяльності (Пишнов, 2012). Ї̈̈ сутність представлено у табл. 1 .

(C) Miroshnychenko Olena, Pasichnyk Igor DOI (article): https://doi.org/10.32626/2227-6246.2020-48.228-252 


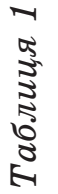

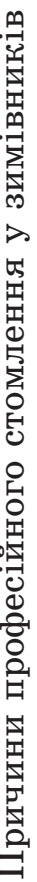

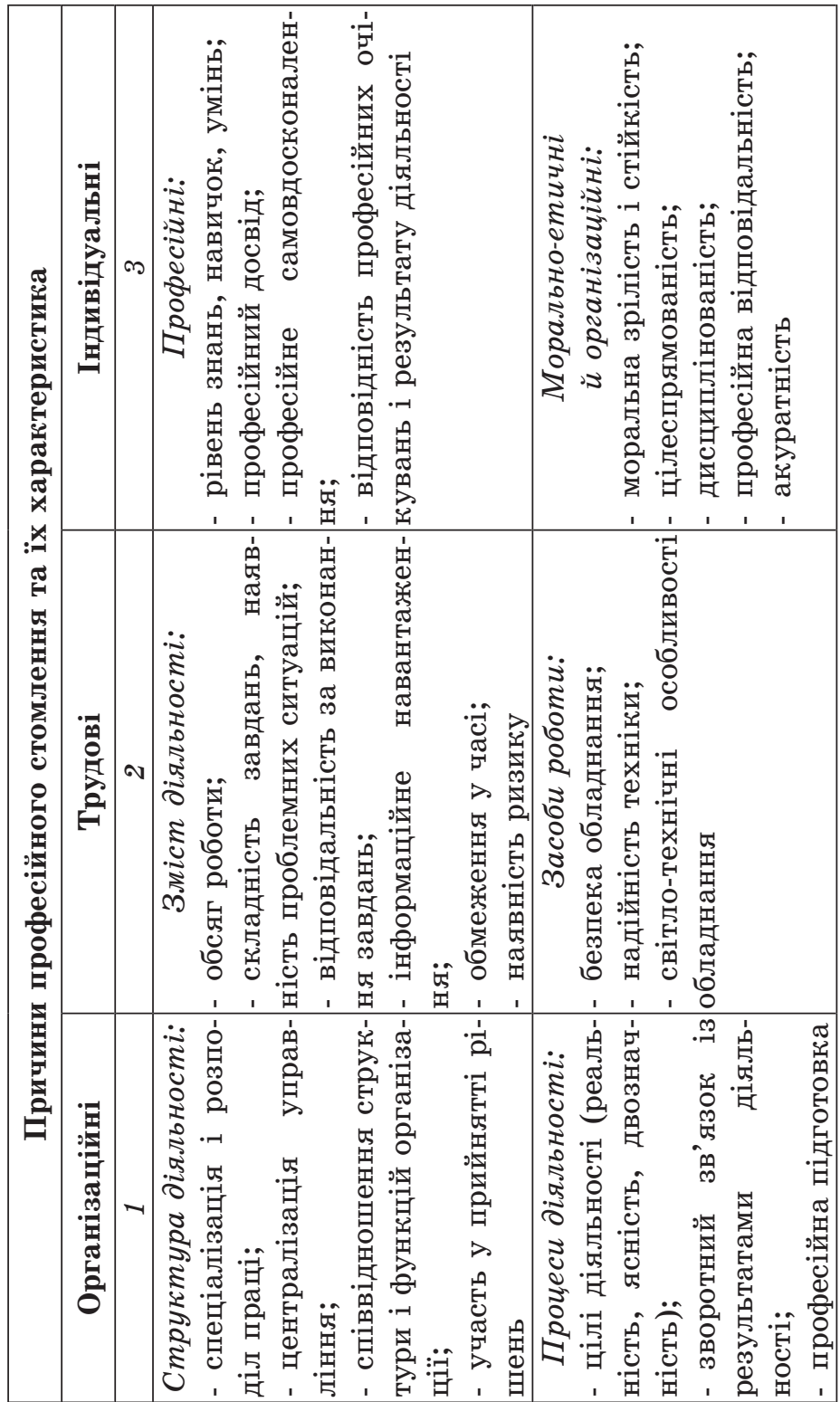

(C) Miroshnychenko Olena, Pasichnyk Igor

DOI (article): https://doi.org/10.32626/2227-6246.2020-48.228-252 


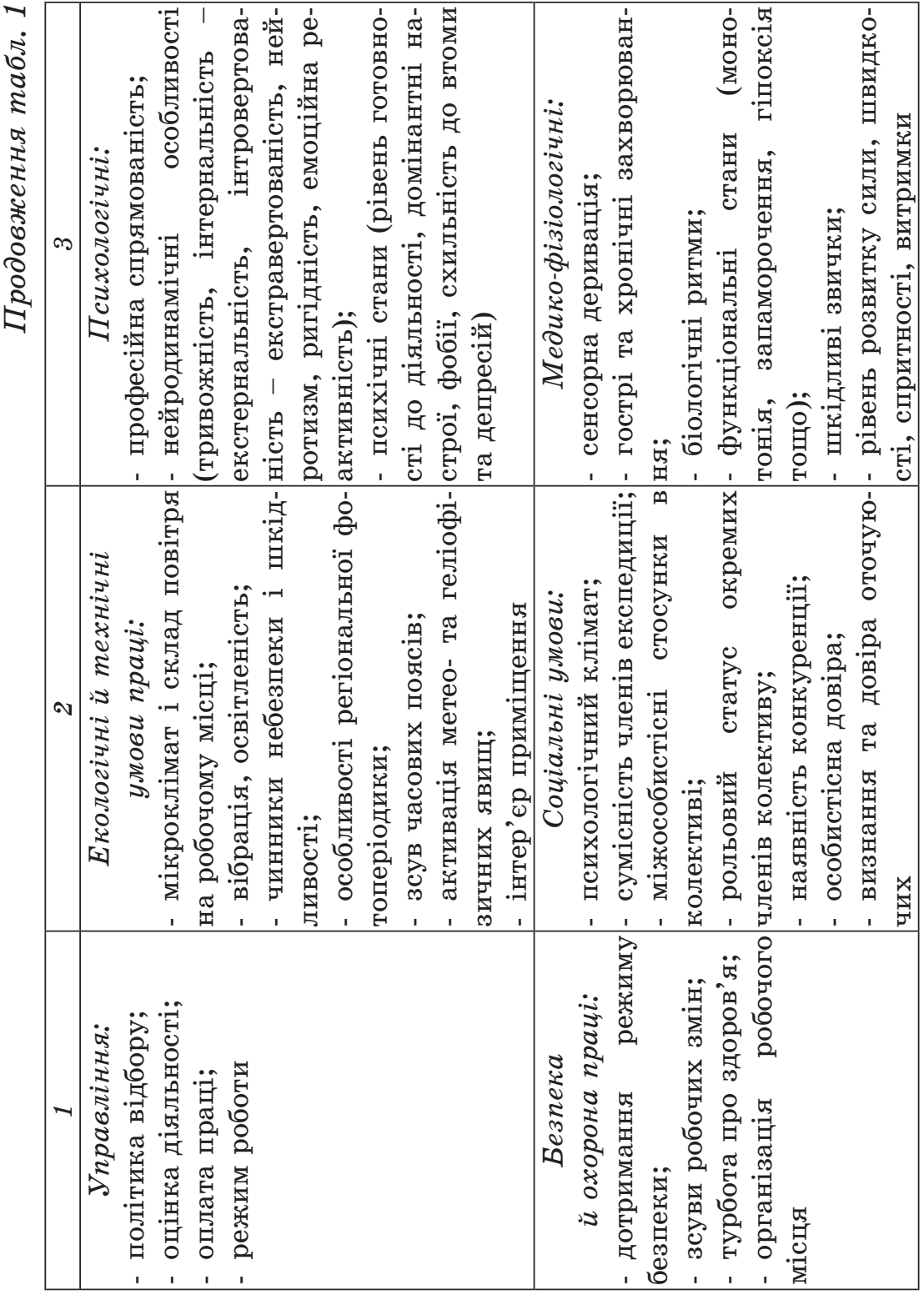

(C) Miroshnychenko Olena, Pasichnyk Igor DOI (article): https://doi.org/10.32626/2227-6246.2020-48.228-252 
Ознаки професійного стомлення в екстремальних умовах життєдіяльності проявлялися в окремих зимівників як результат недостатньої адаптації, як правило, через 3-4 місяці з початку експедиції, оскільки в цей період настає антарктична зима з майже відсутністю світлового часу доби, а також підсилюється сум за близькими, котрі залишилися вдома. Погіршення психологічних показників стану особистості залежить ще й від віку зимівників.

Для експериментальної перевірки власних спостережень ми умовно розподілили зимівників кожної експедиції на вікові групи. Цей розподіл грунтувався на дослідженнях, представлених у роботах вітчизняних науковців. Так, Я. Васильєв, проаналізувавши дані психологічних розробок останніх років, пропонує виокремлення у дорослому віці таких періодів: період молодості - від 21 до 27 років, дорослішання - 28-34 роки, дорослість - 35-45 років, зрілість 46-55 років, пізня зрілість - 56-66 років, старіння - 67-78 років і далі - старість (Васильєв, 2009: 306-308).

К. Крутій і Л. Зданевич пропонують іншу (соціально-психологічну) основу для виокремлення вікових періодів у житті дорослої людини нашого часу (Крутій \& Зданевич, 2017). Ця періодизація базується на теорії поколінь, згідно з якою дорослі люди сучасності поділяються на вікові групи залежно від років народження: 1947-1967 р. н. - покоління «Діти переможців», або «Бебі-Бумери», народжені після Другої світової війни (у нашому дослідженні це зимівники 46-62 років); 1968-1987 р. н. - покоління «Х», або «Невідоме покоління» (у нашому дослідженні це зимівники 35-45 років); 1988-2000 р. н. - покоління «Ү», або покоління « $\mathrm{Mi}$ леніум» (у нашому дослідженні це зимівники 22-34 років) (Крутій \& Зданевич, 2017: 58-59).

Ми представляємо результати психологічних досліджень особливостей адаптації до життєдіяльності в умовах зимівлі у представників різних вікових груп зимівників (усього 70 осіб). Обрані нами показники свідчать про негативні емоцій(c) Miroshnychenko Olena, Pasichnyk Igor

DOI (article): https://doi.org/10.32626/2227-6246.2020-48.228-252 
ні стани особистості зимівника, які запобігають ефективній адаптації. "Сирі» бали методик переведено в 24-бальну систему оцінювання, де показники від 0 до 6 вважаємо низькими, від 7 до 10 - нижче середнього, від 11 до 14 - середніми, від 15 до 17 - вище середнього, 18 і вище - високими.

Перший i другий зрізи відповідають першому i другому замірам із різницею в три місяці: перший зріз проведено у березні відповідного року в кожній із 9 експедицій, а другий - через три місяці у червні. У табл. 2 представлено середні бали показників адаптації у старшій групі досліджуваних (14 зимівників віком від 46 до 62 років).

таблиця 2

Динаміка показників адаптації в групі зимівників покоління «Діти переможців»

\begin{tabular}{|c|c|c|c|c|c|c|c|c|c|c|}
\hline \multirow{2}{*}{$\begin{array}{c}\text { Кількість } \\
\text { досліджу- } \\
\text { ваних - } \\
14\end{array}$} & \multicolumn{2}{|c|}{$\begin{array}{c}\text { Застря- } \\
\text { гання }\end{array}$} & \multicolumn{2}{|c|}{$\begin{array}{c}\text { Педан- } \\
\text { тизм }\end{array}$} & \multicolumn{2}{|c|}{$\begin{array}{c}\text { Тривож- } \\
\text { ність }\end{array}$} & \multicolumn{2}{|c|}{$\begin{array}{c}\text { Дистим- } \\
\text { ність }\end{array}$} & \multicolumn{2}{|c|}{$\begin{array}{c}\text { Збудже- } \\
\text { ність }\end{array}$} \\
\hline & $\begin{array}{c}\text { I } \\
\text { зpi3 }\end{array}$ & & $\begin{array}{c}\text { I } \\
\text { 3pi3 }\end{array}$ & & $\begin{array}{c}I \\
\text { 3pi3 }\end{array}$ & & $\begin{array}{c}\text { I } \\
\text { 3pi3 }\end{array}$ & & $\begin{array}{c}\text { I } \\
\text { зрiз }\end{array}$ & \\
\hline $\begin{array}{l}\text { Середній } \\
\text { бал }\end{array}$ &, 57 & & 9,14 & & 9,29 & & 9,57 & & 9,21 & 9,40 \\
\hline $13 \mathrm{H}$ & & & & & & & & & & \\
\hline
\end{tabular}

Як бачимо, усі показники явищ акцентуацій не виходять за межі середніх показників, проте відсоткове зростання негативних емоційних проявів у представників цієї групи складає від $2,4 \%$ до $22,4 \%$. Хоча характерними рисами представників зазначеного покоління вважаються такі позитивні емоційні риси, як оптимізм, досягнення високого результату, зацікавленість в особистісному зростанні й, водночас, колективізм і командний дух, ми виявили збільшення застрягання на невирішених проблемах, а також деяке підвищення тривожності, педантизму, збудженості та дистимності (депресивності) через три місяці від початку зимівлі. Збільшення показників застрягання пояснюється, на нашу

(C) Miroshnychenko Olena, Pasichnyk Igor DOI (article): https://doi.org/10.32626/2227-6246.2020-48.228-252 
думку, тим, що представники старшого покоління у найскладніший період зимівлі відчувають гостру відповідальність за молодших членів експедиції, зимуючих уперше.

У табл. 3 представлено середні бали показників адаптації в середній віковій групі досліджуваних. Вона є другою за чисельністю серед 70 досліджуваних зимівників і складає 25 осіб віком від 35 до 45 років. Представників «Невідомого покоління» прийнято вважати такими, яким притаманні готовність до змін, можливість вибору, самостійність, неформальність поглядів, пошук емоцій, прагматизм, високий рівень матеріальних амбіцій.

Якщо ми порівняємо показники між старшою та середньою групами, то найбільшу різницю спостерігаємо за шкалою «тривожність»: вона є меншою у представників середньої вікової групи. При порівнянні показників у другому зрізі відмінності за $t$-критерієм Стьюдента виявилися значущими $(\mathrm{t}=3,75 ; \mathrm{p}<0,05)$. Цей факт свідчить про більш стійку врівноваженість, упевненість, емоційну стійкість, відтак, і адаптованість у зимівників вікової групи 35-45 років.

таблиця 3

Динаміка показників адаптації в групі зимівників покоління «Х»

\begin{tabular}{|c|c|c|c|c|c|c|c|c|c|c|}
\hline \multirow{2}{*}{$\begin{array}{c}\text { Кількість } \\
\text { досліджу- } \\
\text { ваних - } \\
25\end{array}$} & \multicolumn{2}{|c|}{$\begin{array}{c}\text { Застря- } \\
\text { гання }\end{array}$} & \multicolumn{2}{|c|}{$\begin{array}{c}\text { Педан- } \\
\text { тизм }\end{array}$} & \multicolumn{2}{|c|}{$\begin{array}{c}\text { Тривож- } \\
\text { ність }\end{array}$} & \multicolumn{2}{|c|}{$\begin{array}{c}\text { Дистим- } \\
\text { ність }\end{array}$} & \multicolumn{2}{|c|}{$\begin{array}{c}\text { Збудже- } \\
\text { ність }\end{array}$} \\
\hline & I зріз & & $\begin{array}{c}\text { I } \\
\text { 3pi3 }\end{array}$ & & & & & & $\begin{array}{c}\text { I } \\
\text { 3pi3 }\end{array}$ & \\
\hline Топопій & & & 8,28 & & 4,88 & & 9,28 & & 9,08 & \\
\hline & & & & & & & & & & \\
\hline
\end{tabular}

Як бачимо, у представників «Невідомого покоління» (покоління «Х») середні бали лише за одним показником (педантизм) незначно збільшилися, решта середніх показ() Miroshnychenko Olena, Pasichnyk Igor

DOI (article): https://doi.org/10.32626/2227-6246.2020-48.228-252 
ників мають від'ємну величину: це свідчить про те, що негативні емоційні прояви характеру не лише не збільшилися під впливом екстремальних умов, а навіть зменшилися. Такі дані також свідчать про нервово-психічну й емоційну стійкість зимівників середнього дорослого віку, які беруть участь в антарктичних експедиціях.

У табл. 4 представлено середні бали показників адаптації в молодшій віковій групі досліджуваних (покоління «Міленіум»). Вона є найбільшою за чисельністю серед 70 досліджуваних зимівників і складає 31 особу віком від 22 до 34 років.

Таблиия 4

Динаміка показників адаптації в групі зимівників покоління «Y»

\begin{tabular}{|c|c|c|c|c|c|c|c|c|c|c|}
\hline \multirow{2}{*}{$\begin{array}{c}\text { Кількість } \\
\text { досліджу- } \\
\text { ваних - } \\
\mathbf{3 1} \\
\end{array}$} & \multicolumn{2}{|c|}{$\begin{array}{c}\text { Застря- } \\
\text { гання }\end{array}$} & \multicolumn{2}{|c|}{$\begin{array}{c}\text { Педан- } \\
\text { тизм }\end{array}$} & \multicolumn{2}{|c|}{$\begin{array}{c}\text { Тривож- } \\
\text { ність }\end{array}$} & \multicolumn{2}{|c|}{$\begin{array}{c}\text { Дистим- } \\
\text { ність }\end{array}$} & \multicolumn{2}{|c|}{$\begin{array}{c}\text { Збудже- } \\
\text { ність }\end{array}$} \\
\hline & I зріз & $\begin{array}{c}\text { II } \\
\text { зpi3 }\end{array}$ & $\begin{array}{c}\text { I } \\
\text { 3pi3 }\end{array}$ & \begin{tabular}{|c|} 
II \\
3pi3 \\
\end{tabular} & \begin{tabular}{|c|} 
I \\
3pi3 \\
\end{tabular} & \begin{tabular}{|c|} 
II \\
3pi3
\end{tabular} & \begin{tabular}{|c|} 
I \\
3pi3
\end{tabular} & $\begin{array}{c}\text { II } \\
\text { spi3 }\end{array}$ & $\begin{array}{c}\text { I } \\
\text { 3pi3 }\end{array}$ & \begin{tabular}{|c|} 
II \\
3pi3 \\
\end{tabular} \\
\hline $\begin{array}{l}\text { Середній } \\
\text { бал }\end{array}$ & 10,42 & 10,48 & 8,77 & 9,45 & 6,58 & 6,65 & 8,68 & 8,94 & 7,77 & 7,93 \\
\hline Різниця & $\begin{array}{r}0, \\
(0,6\end{array}$ & $\begin{array}{l}06 \\
6 \%)\end{array}$ & $\begin{array}{r}0, \\
(7,8\end{array}$ & $\begin{array}{l}68 \\
3 \%)\end{array}$ & $\begin{array}{r}0, \\
(1,\end{array}$ & $\begin{array}{l}07 \\
\%)\end{array}$ & & $\begin{array}{l}26 \\
\%)\end{array}$ & & $\begin{array}{l}16 \\
\%)\end{array}$ \\
\hline
\end{tabular}

Як бачимо з табл. 4, середні показники за всіма шкалами мають деяке збільшення, хоча показники явищ акцентуацій у другому зрізі також не виходять за межі середніх показників. Проте, дані за шкалами «дистимність» i «збудженість» вигідно відрізняються від попередніх груп тим, що мають найнижчий показник серед усіх груп. Це свідчить про оптимізм молодості, енергійність, незлопам'ятність. Для покоління «Y» характерно почуття громадянського обов’язку, наявність моралі, відповідальність, слідування моді, бажання відновити суспільство. Схожі позитивні риси ми спостерігаємо і в молодому поколінні українських зимівників.

(C) Miroshnychenko Olena, Pasichnyk Igor DOI (article): https://doi.org/10.32626/2227-6246.2020-48.228-252 


\section{Висновки}

Дослідження психологічних характеристик особистості займають ключові позиції у системі обстеження фахівців екстремальних видів діяльності та складають основу прогнозування професійної придатності й адаптації індивідуума до умов соціальної ізоляції та перманентного впливу надзвичайної сили чинників навколишнього середовища.

Поряд із загальними закономірностями адаптації, що проявляються на нейродинамічному, психологічному та соціальному рівнях, ми враховуємо той факт, що адаптивна поведінка особистості в екстремальних умовах характеризується прийняттям рішення, правом ініціативи і точним визначенням свого майбутнього. Така особистість переважно має нормальну незахисну форму адаптації, вона не відходить від проблемних ситуацій, а використовує їх для реалізації своїх цілей, сама планує, здійснює своє майбутне та переборює труднощі. Такі особистості складають більшість зимівників на українській антарктичній станції.

Проведений аналіз показників адаптованості до екстремальних умов життєдіяльності зимівників довів, що робота $з$ підготовки полярників до зимівлі на українській станції «Академік Вернадський», яку проводить Національний антарктичний науковий центр Міністерства освіти і науки України, має позитивний результат. Створення умов, наближених до реальних, дає змогу під час підготовки до зимівлі відпрацювати основні моменти тих складнощів, які можуть очікувати зимівників упродовж року.

3 урахуванням визначених показників ми робимо висновки щодо готовності кандидатів на учасників зимових експедицій до життєдіяльності в умовах Антарктики. Перевага надається кандидатам, які мають показники сильної, врівноваженої нервової системи, професійно-результативну та соціальну мотивацію на діяльність, високі показники адаптації до екстремальних і стресових умов та у яких відсутні високі показники акцентуацій характеру.

C Miroshnychenko Olena, Pasichnyk Igor

DOI (article): https://doi.org/10.32626/2227-6246.2020-48.228-252 http://journals.uran.ua/index.php/2227-6246 
Доведено, що найадаптованішою віковою групою щодо життєдіяльності в умовах Антарктики є представники середньої дорослості віком від 35 до 45 років. Представники цієї групи складають близько $40 \%$ учасників українських антарктичних експедицій, що свідчить про достатній рівень психологічної стабільності команд зимівників.

\section{Література}

Васильев Я. В. Структура и функции целевого компонента направленности личности: дис. ... д-ра психол. наук: 19.00.01. Николаев, 2009. 416 c.

Корольчук М. С., Крайнюк В. М. Соціально-психологічне забезпечення діяльності в звичайних та екстремальних умовах. Київ : НікаЦентр, 2006. 578 с.

Крутій К. Л., Зданевич Л. В. Огляд емпіричних досліджень щодо стратифікації сучасного дошкільного дитинства. Development and modernization of social sciences: experience of Poland and prospects of Ukraine. Lublin : Izdevnieciba «Baltija Publishing», 2017. Vol. 2. C. 56-71.

Мирошниченко О. А. Роль темперамента зимовщика в процессе адаптации к условиям жизнедеятельности в Антарктике. Наука і освіта. Психологія: наук.-практ. журнал. Одеса : «Південноукраїнський національний педагогічний університет імені К. Д. Ушинського», 2016. № 7/CXXXVIII. C. 126-132.

Мірошниченко О. А., Гуцуляк О. П., Марченко О. В. Впровадження діагностичних процедур і тренінгових програм у психологічну підготовку та реабілітацію зимівників. Украйнський антарктичний журнал. Київ : Український фітосоціологічний центр, 2018. № 16. С. 178-187.

Мірошниченко О. А., Моісеєнко Є. В., Литвинов В. А. Основи психофізіологічних та психологічних умов діяльності. ЖКитомир : Рута, 2015. 296 c.

Налчаджян А. А. Психологическая адаптация: механизмы и стратегии. Москва : Эксмо, 2010. 386 с.

Пишнов Г. Ю. Психофізіологічні механізми формування хронічного стомлення при високій напруженості праці: дис. ... д-ра мед. наук: 14.02.01. Київ, 2012. 396 с.

Райгородский Д. Я. Практическая диагностика. Методики и тесты. Самapa : «БAXPAX-M», 2008. 672 с.

(C) Miroshnychenko Olena, Pasichnyk Igor

DOI (article): https://doi.org/10.32626/2227-6246.2020-48.228-252 
Bakhmutova, L. (2019). Factors and models of interpersonal interaction of participants in long-term Ukrainian Antarctic Expeditions. Fundamental and applied researches in practice of leading scientific schools, 36 (6), 48-55.

Mehta, M., \& Chugh, G. (2011). Achievement Motivation and Adjustment in Members of Indian Scientific Expedition to Antarctica. Psychological Studies, 56 (4).

Moiseienko, E., Sukhorukov, V., Pyshnov, H., Mankovska, I., Rozova, K., \& Miroshnychenko, O. (2016). Antarctica challenges the new horizons in predictive, preventive, personalized medicine: preliminary results and attractive hypothesis for multidisciplinary prospective studies in the Ukrainian "Akademik Vernadsky» station. EPMA Journal, 7 (1). (Article 11).

Perelyhina, L., \& Mykhliuk E. (2017). The dynamics of manifestation of professionally caused accentuations in employees of the state emergency service of Ukraine. Development and modernization of social sciences: experience of Poland and prospects of Ukraine, 1, 305-322. Lublin : Izdevnieciba «Baltija Publishing».

Sannikov O. (2016). Information system operator: the structure and components of personal choice. Наука і освіта. Психологія : наук.практ. журнал. Одеса : «Південноукраїнський національний педагогічний університет імені К. Д. Ушинського». № 7/CXXXVIII. C. $133-143$.

\section{References}

Vasiliev, Ya. V. (2009). Struktura i funktsii tselevogo komponenta napravlennosti lichnosti [Structure and functions of the target component of personality orientation]. Doctor's thesis. Nikolaiev [in Russian].

Korolchuk, M. S., \& Krainiuk, V. M. (2006). Sotsialno-psykholohichne $z a$ bezpechennia diialnosti $v$ zvychainykh ta ekstremalnykh umovakh [Socio-psychological support of activities in the ordinary and extreme conditions]. Kyiv : Nika-Tsentr [in Ukrainian].

Krutii, K. L., \& Zdanevych, L. V. (2017). Ohliad empirychnykh doslidzhen shchodo stratyfikatsii suchasnoho doshkilnoho dytynstva [Review of empirical research on the stratification of modern preschool childhood]. Development and modernization of social sciences: experience of Poland and prospects of Ukraine, 2, 56-71. Lublin : Izdevnieciba «Baltija Publishing» [in Ukrainian].

Miroshnichenko, O. A. (2016). Rol temperamenta zimovshchika v protsesse adaptatsii $\mathrm{k}$ usloviiam zhiznedeiatelnosti $\mathrm{v}$ Antarktike [The role of the temperament of the winterer in the process of adaptation to the

(c) Miroshnychenko Olena, Pasichnyk Igor

DOI (article): https://doi.org/10.32626/2227-6246.2020-48.228-252 http://journals.uran.ua/index.php/2227-6246 
conditions of life in the Antarctica]. Nauka i osvita. Psykholohiia Science and Education. Psychology: Scientific and Practical Journal, 7, 126-132 [in Russian].

Miroshnychenko, O. A., Hutsuliak, O. P., \& Marchenko, O. V. (2018). Vprovadzhennia diahnostychnykh protsedur i treninhovykh prohram $\mathrm{u}$ psykholohichnu pidhotovku ta reabilitatsiiu zymivnykiv [The implementation of diagnostic procedures and training programs in the psychological preparation and rehabilitation of winterers]. Ukrainskyi antarktychnyi zhurnal - Ukrainian Antarctic Journal, 16, 178187 [in Ukrainian].

Miroshnychenko, O. A., Moiseienko, Ye. V., \& Lytvynov, V. A. (2015). Osnovy psykhofiziolohichnykh ta psykholohichnykh umov diialnosti [Fundamentals of psychophysiological and psychological conditions of activity]. Zhytomyr : Ruta [in Ukrainian].

Nalchadzhian, A. A. (2010). Psikhologicheskaia adaptatsiia: mekhanizmy $i$ strategii [Psychological Adaptation: Mechanisms and Strategies]. Moskva : Eksmo [in Russian].

Pyshnov, H. Yu. (2012). Psykhofiziolohichni mekhanizmy formuvannia khronichnoho stomlennia pry vysokii napruzhenosti pratsi [Psychophysiological mechanisms of formation of chronic fatigue at high labor intensity]. Doctor's thesis. Kyiv [in Ukrainian].

Raigorodskii, D. Ya. (2008). Prakticheskaia diagnostika. Metodiki i testy [Practical diagnostics. Procedures and tests]. Samara : "BAKhRAKh-M» [in Russian].

Bakhmutova, L. (2019). Factors and models of interpersonal interaction of participants in long-term Ukrainian Antarctic Expeditions. Fundamental and applied researches in practice of leading scientific schools, 36 (6), 48-55.

Mehta, M., \& Chugh, G. (2011). Achievement Motivation and Adjustment in Members of Indian Scientific Expedition to Antarctica. Psychological Studies, 56 (4).

Moiseienko, E., Sukhorukov, V., Pyshnov, H., Mankovska, I., Rozova, K., \& Miroshnychenko, O. (2016). Antarctica challenges the new horizons in predictive, preventive, personalized medicine: preliminary results and attractive hypothesis for multidisciplinary prospective studies in the Ukrainian "Akademik Vernadsky» station. EPMA Journal, 7 (1). (Article 11).

Perelyhina, L., \& Mykhliuk, E. (2017). The dynamics of manifestation of professionally caused accentuations in employees of the state emergency service of Ukraine. Development and modernization of social sciences: experience of Poland and prospects of Ukraine, 1, 305-322. Lublin : Izdevnieciba «Baltija Publishing» .

(C) Miroshnychenko Olena, Pasichnyk Igor

DOI (article): https://doi.org/10.32626/2227-6246.2020-48.228-252 
DOI: https://doi.org/10.32626/2227-6246.2020-48 2020. випуск 48

Sannikov, O. (2016). Information system operator: the structure and components of personal choice. Nauka i osvita. Psykholohiia - Science and Education. Psychology: Scientific and Practical Journal, 7, 133143.

\section{Мірошниченко Олена, Пасічник Ігор. Вікові особливості психологічної адаптації українських зимівників до життєдіяльності в умовах Ан- тарктики}

\section{АНОТАЦІЯ}

У статmі розглянуто особливості психологічної адаптації зимівників до екстремальних умов життєдіяльності. Зимівля українських полярників, які проводять дослідження за напрямами, затвердженими Державною програмою, пов'язана з тривалим перебуванням на обмеженій території, що вимагає адаптації до соціальної ізоляції та психологічної депривації. Крім того, адаптація зимівників проходить в умовах суворого клімату, і багато в чому залежить від готовності учасників експедиції до виконання професійних обов'язків у екстремальних умовах.

Мета статmі - представити теоретичні основи та практичні результати досліджень вікових особливостей психологічної адаптації українських зимівників до життєдіяльності в умовах Антарктики на прикладі 9 останніх експедицій до української антарктичної станції "Академік Вернадський».

Використано комплекс методів психологічних досліджень адаптаційних процесів особистості певного віку. В експерименті взяли участь 70 зимівників, які перебували в Антарктиді упродовж року в період 20112019 рр.

Результати дослідження. Надано результати емпіричних досліджень щодо показників адаптації у зимівників різних вікових груп за попередні зимівлі. Співставлення результатів обстеження під час експедиції виявило наявність змін психологічних характеристик. З’ясовано, що в окремих зимівників під час перебування в Антарктиці мали місце психоемочійні проблеми, були виявлені типові психологічні та психофізіологічні зрушення. Установлено, що найскладнішим періодом життєдіяльності виявився період антарктичної зими.

Висновок. Доведено, що найадаптованішою віковою групою щодо життєдіяльності в умовах Антарктики є представники середньої дорос(C) Miroshnychenko Olena, Pasichnyk Igor

DOI (article): https://doi.org/10.32626/2227-6246.2020-48.228-252 http://journals.uran.ua/index.php/2227-6246 
DOI: https://doi.org/10.32626/2227-6246.2020-48 2020. виПУСК 48

лості віком від 35 до 45 років. Представники цієї групи складають близько 40\% учасників українських антарктичних експедицій, що свідчить про достатній рівень психологічної стабільності команд зимівників.

Ключові слова: адаптація, адаптивність, життєдіяльність в умовах Антарктики, готовність, підготовка до екстремальної діяльності, вікові групи дорослості.

Мирошниченко Елена, Пасичник Игорь. Возрастные особенности психологической адаптации украинских зимовщиков к жизнедеятельности в условиях Антарктики

\section{АННОТАЦИЯ}

В статье рассмотрены особенности психологической адаптации зимовщиков к экстремальным условиям жизни. Зимовка украинских полярников, которые проводят исследования по направлениям, утвержденным государственной программой, связана с длительным пребыванием на ограниченной территории, что требует адаптации к социальной изоляции и психологической депривации. Кроме того, адаптация зимовщиков проходит в суровых условиях и во многом зависит от готовности участников экспедиции выполнять профессиональные обязанности в экстремальных условиях.

Цель статьи - представить теоретические основы и практические результаты исследований возрастных особенностей психологической адаптации украинских зимовщиков к жизни в антарктических условиях на примере 9 последних экспедиций на украинскую антарктическую станцию "Академик Вернадский».

Использован комплекс методов психологического исследования адаптационных процессов определенного возраста личности. В эксперименте приняли участие 70 зимовщиков, которые находились на Антарктиде в течение года в период 2011-2019 гг.

Результаты исследования. Приведены результаты эмпирических исследований по показателям адаптации зимовщиков разных возрастных групп за предыдущие зимовки. Сопоставление результатов обследования во время экспедиции обнаружило наличие изменений психологических характеристик. Установлено, что у отдельных зимовщиков во время пребывания в Антарктике имели место психоэмоциональные проблемы, были обнаружены типичные психологические и психофизио-

(C) Miroshnychenko Olena, Pasichnyk Igor DOI (article): https://doi.org/10.32626/2227-6246.2020-48.228-252 
DOI: https://doi.org/10.32626/2227-6246.2020-48

логические нарушения. Установлено, что наиболее сложным периодом жизнедеятельности оказался период антарктической зимы.

Вывод. Доказано, что наиболее адаптированной возрастной группой к жизнедеятельности в условиях Антарктиды являются представители среднего зрелого возраста от 35 до 45 лет. Представители этой группы составляют около 40\% участников украинских антарктических экспедиций, что свидетельствует о достаточном уровне психологической устойчивости команд зимовщиков.

Ключевые слова: адаптация, адаптивность, жизнедеятельность в условиях Антарктики, готовность, подготовка к экстремальной деятельности, возрастные группы взрослости.

Original manuscript received February 20, 2020 Revised manuscript accepted March 10, 2020

(C) Miroshnychenko Olena, Pasichnyk Igor

DOI (article): https://doi.org/10.32626/2227-6246.2020-48.228-252 http://journals.uran.ua/index.php/2227-6246 